American Journal of Animal and Veterinary Sciences 5 (1): 8-12, 2010

ISSN 1557-4555

(C) 2010 Science Publications

\title{
Age and Growth of Brown Trout (Salmo trutta) in Six Rivers of the Southern Part of Caspian Basin
}

\author{
${ }^{1}$ Azarmidokht Kheyrandish, ${ }^{1}$ Asghar Abdoli, ${ }^{1}$ Hossein Mostafavi, \\ ${ }^{1}$ Hamid Niksirat, ${ }^{2}$ Mehdi Naderi and ${ }^{2}$ Saber Vatandoost \\ ${ }^{1}$ Environmental Sciences Research Institute, \\ Department of Biodiversity and Ecosystem Management, \\ Shahid Beheshti University, GC, 1983963113, Tehran, Iran \\ ${ }^{2}$ Department of Ecology, Caspian Ecology Academy, \\ Iranian Fisheries Research Organization, Iran
}

\begin{abstract}
Problem statement: Because of dramatic declines in stocks of brown trout in southern part of Caspian basin, the population's structure of brown trout (Salmo trutta) in several rivers were studied to provide data for conservation programs. Approach: The structure of the populations in the six rivers of the southern part of Caspian basin including: Keliyare, Khojirood, Lar, Shirinrood, Rig cheshme and Pajimiyane, were studied. Results: Five age classes, ranged from $0^{+}-4^{+}$years, were determined. The most frequent age classes belong to $1^{+}$and $2^{+}$. The length ranged from $78-305 \mathrm{~mm}$ and weight ranged from 3.6-390 g. Also, the condition factor ranged from 0.58-1.47. The highest and lowest length, weight and condition factor were observed in Lar and Rig cheshme, respectively. In 5 out of 6 rivers, females were dominant over males. The highest and lowest female: Male ratios were observed in Pajimiane (6.75:1) and Khojirood (0.8:1), respectively. Significant relationships were found between total length of brown trout with depth $(r=0.6, p<0.0001)$ and width $(r=0.68, p<0.0001)$ of habitats in these studied areas. Conclusion: According to our knowledge, this is the first report of brown trout from Kelyare and Khojirood rivers. Since size of populations in studied areas are small and majority of these rivers located in low protected locations, it is essential to apply serious measures to protect these vulnerable habitats.
\end{abstract}

Key words: Brown trout, age, growth, Caspian basin

\section{INTRODUCTION}

The brown trout, Salmo trutta, is a native species for Iran. This species prefers cold upstream and mountain lakes with rich oxygen contents and feeds from small fishes and aquatic insects. The brown trout has economic and conservation values. Many of them are caught by sport fishermen every year in Lar and other regions. Unfortunately, the populations of brown trout are declining as a result of overfishing, water pollution, habitat destruction, drought (Abdoli, 2000). To support conservation programs, basic knowledgments must be provided (Elliott, 1989). The study of weight-length relationship and condition factor are useful because they have also been used for the comparison of species growth between regions (Koutrakis and Tsikliras, 2003).
Also, the length-weight relationship helps in predicting the condition, reproductive history and life history of fish species (Nikolsky, 1963; Pauly, 1993; Wootton, 1992). The abundance of trout depends on conservation of natural river and stream habitats, as well as on their protection during the trout spawning period (Skrupskelis et al., 2006).

There is a lack of information on biological traits of brown trout in Iran. The aim of present study was to provide information about basic biological traits of brown trout in six main rivers in north part of Iran. In addition, it was hypothesized that the lengths of brown trout correlate with sizes of their habitats.

\section{MATERIALS AND METHODS}

Fish were caught from six rivers including Kelyare, Khojirood, Lar, Pajimianeh, Shirinrood and

Corresponding Author: H. Niksirat, Environmental Sciences Research Institute,

Department of Biodiversity and Ecosystem Management, Shahid Beheshti University, GC, 1983963113, Tehran, Iran Tel: 0098-21-22431971 Fax: 0098-21-22431972 
Rigcheshme located in Mazandaran province, north part of Iran, during autumn of 2006 using an electrofishing gear (200-300 volt). The shocked samples were collected using a net (mesh size $5 \mathrm{~mm}$ ) installed downstream. In the laboratory, total length of specimens were measured to the nearest $\mathrm{mm}$ and total weight determined using a digital balance to an accuracy of $0.01 \mathrm{~g}$. Scales were used to determine fish age. The Condition Factor (CF) was calculated according:

$\mathrm{CF}=\left(\mathrm{W} / \mathrm{L}^{3}\right) \times 100$

Where:

$\mathrm{W}=$ The wet weight $(\mathrm{g})$

$\mathrm{L}=$ Total length $(\mathrm{cm})$

The relation of weight to length was calculated according:

$\operatorname{Ln}(\mathrm{W})=\ln (\mathrm{a})+\mathrm{b} \ln (\mathrm{TL})$

The instantaneous growth rate was calculated according (Bagenal, 1978):

$\mathrm{G}=\left(\log \mathrm{w}_{\mathrm{t}+1}-\log \mathrm{w}_{\mathrm{t}}\right) / \Delta \mathrm{t}$

The Pearson's correlation was used to test relationships between sizes of habitat with lengths of brown trout. The width and depth of each river were considered as indexes of habitat sizes. Statistical analyses were carried out using SPSS (version 14) and Excel.

\section{RESULTS}

Significant relationships were found between length and weight in studied rivers (Table 1). The highest and lowest length and weight observed in Lar and Rigcheshme rivers, respectively. The highest age class was $4^{+}$years. The widest ranges for age classes $\left(0^{+}-4^{+}\right)$were observed in Shirinrood and Lar rivers (Fig. 1). The highest and lowest female: Male ratio were observed in Pajimiane and Khojirood, respectively. The condition factor ranged from 0.58 1.47 (Table 2).

Table 3 shows the physico-chemical properties of water in studied rivers. Significant relationships were found between total length of brown trout with depth $(\mathrm{r}=0.6, \mathrm{p}<0.0001)$ and width $(\mathrm{r}=0.68, \mathrm{p}<0.0001)$ of habitats in these studied areas.

Table 1: The length-weight relationships of brown trout in studied

\begin{tabular}{lllr}
\multicolumn{1}{c}{ rivers } & & & \\
\hline Location & Equation & $\mathrm{R}^{2}$ & $\mathrm{n}$ \\
\hline Kelyare & $\operatorname{lnTW}=3 \operatorname{lnTL}-11.6$ & 0.95 & 30 \\
Khojirood & $\operatorname{lnTW}=3.4 \operatorname{lnTL}-13.5$ & 0.97 & 9 \\
Lar & $\operatorname{lnTW}=3.2 \operatorname{lnTL}-13.3$ & 0.97 & 35 \\
Pajimiane & $\operatorname{lnTW}=3.1 \operatorname{lnTL}-11.9$ & 0.99 & 31 \\
Rigcheshme & $\operatorname{lnTW}=3.4 \operatorname{lnTL}-13.7$ & 0.93 & 25 \\
Shirinrood & $\operatorname{lnTW}=3.2 \operatorname{lnTL}-12.6$ & 0.98 & 41 \\
\hline
\end{tabular}

Table 2: The mean length, weight and condition factor of different ages of brown trout in studied rivers (mean \pm SEM)

\begin{tabular}{|c|c|c|c|c|}
\hline Age & Total length (mm) & Total weight $(\mathrm{g})$ & Growth rate & Condition factor \\
\hline \multicolumn{5}{|c|}{ Kelyare } \\
\hline $1^{+}$ & $102.60 \pm 1.74$ & $10.34 \pm 0.60$ & & $0.94 \pm 0.025$ \\
\hline $2^{+}$ & $151.10 \pm 5.80$ & $33.96 \pm 2.49$ & 0.520 & $0.99 \pm 0.047$ \\
\hline \multicolumn{5}{|c|}{ Khojirood } \\
\hline $1^{+}$ & $121.98 \pm 4.90$ & $20.42 \pm 2.22$ & & $1.12 \pm 0.012$ \\
\hline $2^{+}$ & $152.30 \pm 4.93$ & $36.05 \pm 3.55$ & 0.250 & $1.03 \pm 0.100$ \\
\hline $3^{+}$ & 175.68 & 71.56 & 0.300 & 1.32 \\
\hline \multicolumn{5}{|l|}{ Lar } \\
\hline $1^{+}$ & $128.99 \pm 6.46$ & $24.21 \pm 4.52$ & & $1.12 \pm 0.150$ \\
\hline $2^{+}$ & $184.05 \pm 6.28$ & $82.17 \pm 10.01$ & 0.530 & $1.21 \pm 0.035$ \\
\hline $3^{+}$ & $236.09 \pm 5.58$ & $167.95 \pm 13.69$ & 0.310 & $1.25 \pm 0.035$ \\
\hline $4^{+}$ & $255.05 \pm 17.35$ & $209.05 \pm 42.44$ & 0.100 & $1.24 \pm 0.001$ \\
\hline \multicolumn{5}{|c|}{ Pajimiane } \\
\hline $1^{+}$ & $106.30 \pm 1.1$ & $13.12 \pm 0.53$ & & $1.08 \pm 0.018$ \\
\hline $2^{+}$ & $143.65 \pm 17.24$ & $37.35 \pm 14.26$ & 0.450 & $1.10 \pm 0.030$ \\
\hline $3^{+}$ & $238.35 \pm 13.45$ & $159.20 \pm 22.34$ & 0.630 & $1.17 \pm 0.030$ \\
\hline \multicolumn{5}{|c|}{ Rigcheshme } \\
\hline $0^{+}$ & $82.90 \pm 1.88$ & $41.90 \pm 0.27$ & & $0.73 \pm 0.010$ \\
\hline $1^{+}$ & $99.88 \pm 1.41$ & $7.78 \pm 0.045$ & 0.270 & $0.75 \pm 0.02$ \\
\hline \multicolumn{5}{|c|}{ Shirinrood } \\
\hline $0^{+}$ & $109.00 \pm 1.27$ & $13.34 \pm 0.86$ & & $1.03 \pm 0.040$ \\
\hline $1^{+}$ & $129.66 \pm 1.44$ & $23.99 \pm 0.94$ & 0.130 & $1.09 \pm 0.017$ \\
\hline $2^{+}$ & $157.80 \pm 3.01$ & $45.22 \pm 3.59$ & 0.270 & $1.13 \pm 0.033$ \\
\hline $3^{+}$ & 185.50 & 64.88 & 0.157 & 1.01 \\
\hline $4^{+}$ & 305.44 & 390.00 & 0.780 & 1.37 \\
\hline
\end{tabular}


American J. Animal \& Vet. Sci., 5 (1): 8-12, 2010

Table 3: The physio-chemical characteristics of studied rivers (mean \pm SEM)

\begin{tabular}{lllllll} 
Location & Depth $(\mathrm{m})$ & Width $(\mathrm{m})$ & $\mathrm{pH}$ & Salinity $(\%)$ & TDS $\left(\mathrm{mg} . \mathrm{L}^{-1}\right)$ & EC $\left(\mu\right.$ sec. $\left.\mathrm{m}^{-1}\right)$ \\
\hline Shirinrood & 0.31 & 4.80 & $8.38 \pm 0.06$ & 0.300 & $266.30 \pm 3.01$ & $538.00 \pm 6.79$ \\
Pajimiane & 0.23 & 3.20 & $8.53 \pm 0.05$ & $0.211 \pm 0.011$ & $173.60 \pm 3.25$ & $375.70 \pm 12.5$ \\
Khojirood & 0.37 & 2.75 & $8.53 \pm 0.10$ & 0.200 & $231.30 \pm 6.82$ & $467.11 \pm 15.8$ \\
Kelyare & 0.15 & 2.40 & $8.56 \pm 0.03$ & $0.210 \pm 0.01$ & $169.76 \pm 3.92$ & $342.00 \pm 6.85$ \\
Rigcheshme & 0.20 & 2.90 & $8.64 \pm 0.08$ & $0.110 \pm 0.01$ & $156.31 \pm 10.7$ & $259.22 \pm 29.48$ \\
Lar & 0.35 & 7.00 & $8.70 \pm 0.10$ & - & $206.00 \pm 70$ & $491.00 \pm 51.00$ \\
\hline
\end{tabular}

Table 4: The mean length, weight and condition factor of different sex and sex ratio of brown trout in studied rivers (mean \pm SEM)

\begin{tabular}{|c|c|c|c|c|c|c|}
\hline & \multicolumn{2}{|l|}{ Kelyare } & \multicolumn{2}{|l|}{ Khojirood } & \multicolumn{2}{|l|}{ Lar } \\
\hline & Male & Female & Male & Female & Male & Female \\
\hline $\mathrm{TL}(\mathrm{mm})$ & $137.45 \pm 11.59$ & $110.94 \pm 4.23$ & $149.93 \pm 8.14$ & $146.01 \pm 11.72$ & $203.03 \pm 10.55$ & $196.98 \pm 9.53$ \\
\hline W $(\mathrm{g})$ & $25.12 \pm 5.51$ & $15.08 \pm 12.13$ & $40.89 \pm 8.72$ & $31.06 \pm 5.76$ & $112.41 \pm 18.05$ & $110.62 \pm 14.7$ \\
\hline $\mathrm{CF}$ & $0.89 \pm 0.046$ & $0.97 \pm 0.025$ & $1.14 \pm 0.06$ & $1.014 \pm 0.15$ & $1.15 \pm 0.035$ & $1.27 \pm 0.03$ \\
\hline \multirow[t]{2}{*}{ Female: Male } & $3.3: 1$ & & $0.8: 1$ & & $1.2: 1$ & \\
\hline & Pajimiane & & Rigcheshme & & Shirinrood & \\
\hline $\mathrm{TL}(\mathrm{mm})$ & $112.80 \pm 2.37$ & $120.65 \pm 7.48$ & $101.84 \pm 2.32$ & $92.92 \pm 2.2$ & $139.89 \pm 4.79$ & $139.47 \pm 8.31$ \\
\hline W (g) & $16.23 \pm 0.86$ & $27.06 \pm 7.85$ & $8.40 \pm 0.58$ & $6.13 \pm 0.56$ & $33.41 \pm 3.8$ & $41.23 \pm 15.99$ \\
\hline CF & $1.13 \pm 0.03$ & $1.08 \pm 0.02$ & $0.79 \pm 0.01$ & $0.74 \pm 0.02$ & $1.15 \pm 0.02$ & $1.06 \pm 0.02$ \\
\hline Female: Male & $6.75: 1$ & & $1.5: 1$ & & $1.3: 1$ & \\
\hline
\end{tabular}
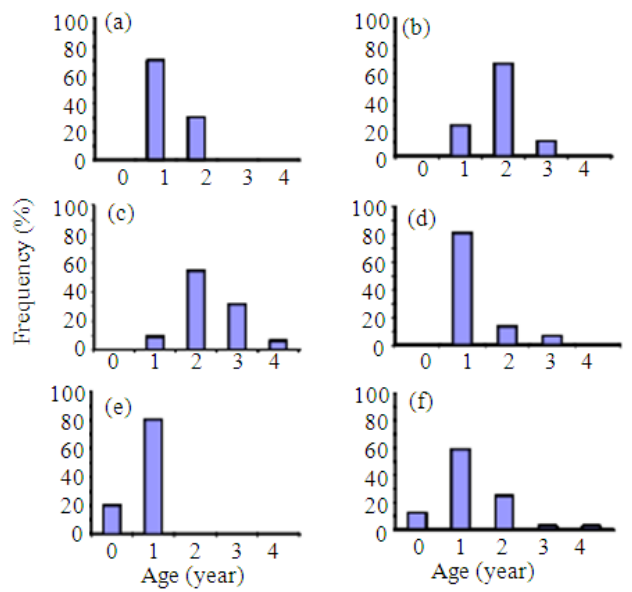

Fig. 1: The frequency of different ages of brown trout in studied rivers; (a) Kelyare; (b) Khojirood; (c) Lar; (d) Pajimiane; (e) Rigcheshme; (f) Shirinrood

\section{DISCUSSION}

According to the results of present study, the brown trout exhibited large among-rivers variation in biological traits (Table 4). The variations in biological traits are most likely to be a consequence of a mixture of factors interacting together. One of the main factors that may be responsible is the size of habitat. Jonsson et al. (2001) concluded that several traits of brown trout are strongly influenced by habitat variables associated with the size of small nursery streams.
In Mosquito Fish Gambusia affinis (Baird and Girard) the water level has been found to influence body size of adults (Skrupskelis et al., 2006; Stearns, 1983a; 1983b). Also, in salmonids, there are differences in adult size among freshwater resident and sea run migratory morphs from the same populations (Jonsson and Jonsson, 1993) and in Arctic Charr Salvelinus alpinus (L.), body size varies among phenotypes exploiting different habitats of the same lake, as a consequence of food abundance and habitat constraints (Jonsson et al., 1988; Jnasson et al., 1998).

In addition, brown trout smolt size increases with latitude, probably as an effect of decreasing water temperature towards the north (Jonsson and L'Abée-Lund, 1993; L'Abée-Lund et al., 1989).

The impact of species diversity on trout growth in young age groups can be accounted for by interspecific competition for food and shelter (Vehanen et al., 1999). A different situation was observed in older age groups $2^{+}$and $3^{+}$, where the highest growth rate was recorded in the central lowland region and was significantly different from those of the other two regions. This can be attributed to the predatory nature of 3-year and older trout (Jonsson and Jonsson, 1999; L'Abee-Lund et al., 2002) that represent the top of the trophic chain in trout streams.

Besides, the trout growth rate in the above age groups was found to be higher in rivers with higher species diversity, which explains the diet of adult trout. Fish communities that are richer in species diversity are usually more abundant, therefore trout finds more potential food items. 
One of the other main factors that may be responsible for change in the size at maturity is fishing mortality. Maturity responses such as decrease in size at maturity may mirror reduction in population size (Trippel, 1995). Most studies indicate that a decrease in size at maturity is caused by compensatory responses to declining population size and/or by genetic selection. The compensatory responses are based on density dependent mechanisms (Bowering and Brodie, 1991; Diana, 1983; Healey, 1980; Nikolsky, 1963) while genetic selection of early maturating fish is a consequence of a high level of stock exploitation. Maturing at a younger age and smaller size may allow individuals to contribute in one or two spawning seasons before they are captured with selective fishing gear because larger individuals are less likely to survive to reproduce (Cardinale and Modin, 1999).

Obvious differences were observed in sex ratio for studied rivers. Maitland and Campbell (1992) mentioned that the number of males in migrating trout populations was more abundant than females. In the freshwater fish the number of males in the early life stages becomes higher than that of females, but in the upper ages the rate of males decreases (Nikolsky, 1963).

\section{CONCLUSION}

According to our knowledge, this is the first report of brown trout from Kelyare and Khojirood rivers. Since size of populations in studied areas are small and majority of these rivers located in low protected locations, it is essential to apply serious measures to protect these vulnerable habitats.

\section{ACKNOWLEDGMENT}

This research was supported by grant no. 600/2936 by research council of University of Shahid Beheshty to A. Kheyrandish.

\section{REFERENCES}

Abdoli, A., 2000. Inland Water Fishes of Iran. Iranian Museum of Nature and Wild Life. 1st Edn., Tehran, ISBN: 964-6902-01-4, pp: 378..

Bagenal, T., 1978. Methods for Assessment of Fish Production in Fresh Waters. 3rd Edn., Blackwell Scientific Publications, Oxford, UK., ISBN: 0632001259, pp: 365.

Bowering, W.R. and W.B. Brodie, 1991. Distribution of commercial flatfishes in the NewfoundlandLabrador region of the Canadian Northwest Atlantic and changes in certain parameters since exploitation. Netherland J. Sea Res., 27: 407-422. DOI: 10.1016/0077-7579(91)90042-Y
Cardinale, M. and J. Modin, 1999. Changes in size-atmaturity of Baltic cod (Gadus morhua) during a period of large variations in stock size and environmental conditions. Fish. Res., 41: 285-295. DOI: 10.1016/S0165-7836(99)00021-1

Diana, J.S., 1983. Growth, maturation and production of northern pike in three Michigan lakes. Trans. Am. Fish. Soc., 112: 38-46. DOI: 10.1577/1548-8659

Elliott, J.M., 1989. Growth and size variation in contrasting populations of trout Salmo trutta: An experimental study on the role of natural selection. J. Anim. Ecol., 58: 45-58. http://www.jstor.org/stable/4985

Healey, M.C., 1980. Growth and recruitment in experimentally exploited Lake Whitefish (Coregonus clupeaformis) populations. Can. J. Fish. Aquat. Sci., 37: 255-267. DOI: 10.1139/f80-033

Jnasson, P.M., B. Jonsson and O.T. Sandlund, 1998. Continental rift and habitat formation: Arena for resource polymorphism in Arctic charr. Ambio, 27: 162-169. http://www.jstor.org/stable/4314711

Jonsson, B. and J.H. L'Abée-Lund, 1993. Latitudinal clines in life history variables of Anadromous brown trout in Europe. J. Fish Biol., 43: 1-16. DOI: 10.1111/j.1095-8649.1993.tb01175.x

Jonsson, B. and N. Jonsson, 1993. Partial migration: Niche shift versus sexual maturation in fishes. Rev. Fish Biol. Fish., 3: 348-365. DOI: 10.1007/BF00043384

Jonsson, B., N. Jonsson, E. Brodtkorb and P.J. Ingebrigtsen, 2001. Life-history traits of brown trout vary with the size of small streams. Funct. Ecol., 15: 310-317. DOI: 10.1046/j.13652435.2001.00528.x

Jonsson, B., S. Sklason, S.S. Snorrason, O.T. Sandlund and H. Malmquist et al., 1988. Life history variation of polymorphic Arctic charr in Lake Thingvallavatn, Iceland. Can. J. Fish. Aquat. Sci., 45: 1537-1547. DOI: 10.1139/f88-182

Jonsson, N. and B. Jonsson, 1999. Trade-off between egg mass and egg number in brown trout. J. Fish Biol., 55: 767-783. DOI: 10.1111/j.10958649.1999.tb00716.x

Koutrakis, E.T. and A.C. Tsikliras, 2003. Lengthweight relationships of fishes from three northern Aegean estuarine systems (Greece). J. Applied Ichthyol., 19: 258-260. DOI: 10.1046/j.14390426.2003.00456.x

L'Abée-Lund, J.H., B. Jonsson, A.J. Jensen, L.M. Saettem and T.G. Heggberget et al., 1989. Latitudinal variation in life-history characteristics of sea-run migrant brown trout Salmo trutta. J. Anim. Ecol., 58: 525-542. http://www.jstor.org/stable/4846 
L'Abee-Lund, J.H., P. Aass and H. Saegrov, 2002. Longterm variation in piscivory in a brown trout population: Effect of changes in available prey organisms. Ecol. Freshwater Fish, 11: 260-269. DOI: $10.1034 /$ j.1600-0633.2002.00020.x

Maitland, P.S. and R.N. Campbell, 1992. Freshwater Fishes of the British Isles. 1st Edn., Harper Collins Publishers, London, Sydney, Toronto, ISBN: 0007308507, pp: 368.

Nikolsky, G.W., 1963. The Ecology of Fishes. 1st Edn., Academic Press, London and New York, pp: 352.

Pauly, D., 1993. Fishbyte Section Editorial, Naga. 1st Edn., ICLARM Quart, pp: 16-26.

Skrupskelis, K., V. Kesminas and S. Stakenas, 2006. The Growth of brown trout, Salmo trutta Fario, in different climatic regions of Lithuania. Acta Zool. Lituanica, 16:

286-292. http://www.ekoi.lt/uploads/docs/AZL_2006_4_286 $-292 \% 20$ psl.pdf
Stearns, S.C., 1983a. A natural experiment in life history evolution: Field data on the introduction of mosquito fish (Gambusia affinis) to Hawaii. Evolution, $\quad 37$ 601-617. http://www.jstor.org/stable/2408273

Stearns, S.C., 1983b. The genetic basis of differences in life history traits among six populations of mosquito fish (Gambusia affinis) that shared ancestors in 1905. Evolution, 37: 618-627. http://www.jstor.org/stable/2408274

Trippel, E., 1995. Age at maturity as a stress indicator in fisheries. Bioscience, 45: 759-770. http://www.jstor.org/stable/1312628

Vehanen, T., A. Maki-Petays, J. Aspi and T. Muotka, 1999. Intercohort competition causes spatial segregation in brown trout in artificial streams. J. Fish Biol., 55: 35-46. DOI: 10.1111/j.10958649.1999.tb00654.x

Wootton, R.S., 1992. Fish Ecology. 1st Edn., Great Britain by Thomson Litho Ltd., Scotland, pp: 203. 